\title{
DISTRIBUSI SPASIAL TINGKAT PENCEMARAN AIR DI DAS CITARUM
}

\author{
Andriati Cahyaningsih ${ }^{1}$ dan Budi Harsoyo ${ }^{2}$
}

\begin{abstract}
This study was aimed to describe spatial distribution of water pollutant at Citarum watershed. This study combined remote sensing technology, Geographic Information System (GIS) and water quality data. Information on Citarum watershed was collected from Landsat TM interpretation. Water quality was collected from secondary data of 33 sample point $B O D$ values. All information was procesed by GIS. The data were analysis and plotted into a map described water pollutant distribution at Citarum watershed.
\end{abstract}

\section{Intisari}

Penelitian ini bertujuan untuk menggambarkan distribusi spasial pencemar air di DAS Citarum. Studi ini menggabungkan teknologi penginderaan jauh, Sistem Informasi Geografis (GIS) dan data kualitas air. Informasi tentang DAS Citarum dikumpulkan dari interpretasi Landsat TM. Kualitas air dikumpulkan dari data sekunder dari 33 titik sampel nilai BOD. Semua informasi diproses oleh GIS. Data dianalisis dan diplot ke dalam peta yang menggambarkan distribusi polutan air di DAS Citarum.

Keywords : GIS, pollutant, spatial distribution, watershed

\section{PENDAHULUAN}

Selama beberapa tahun terakhir, Indonesia mengalami begitu banyak masalah lingkungan dan bencana alam. Masalah yang paling hangat saat ini adalah masalah air. Bencana alam yang terjadi, baik berupa longsor lahan, banjir, maupun kekeringan, semuanya berkaitan dengan air. Pencemaran sungai merupakan masalah yang membuat salah satu sumber air tidak dapat digunakan sebagaimana mestinya. Salah satu daerah aliran sungai (DAS) di Indonesia yaitu DAS Citarum mempunyai masalah banjir dan penurunan kualitas air. Banjir yang terjadi disebabkan antara lain oleh erosi dan sedimentasi yang mengakibatkan pendangkalan pada badan air. Selain itu juga dipengaruhi oleh banyaknya sampah yang dibuang ke badan air sehingga terjadi penyumbatan pada beberapa saluran. Penurunan kualitas air diduga disebabkan oleh banyaknya permukiman dan industri yang tumbuh di DAS Citarum.

DAS Citarum merupakan DAS terbesar di Jawa Barat, dengan luas sekitar $6.614 \mathrm{~km}^{2}$ dan panjang sungai 269 km. Sejak tahun 1962

\footnotetext{
${ }^{1}$ Staf Badan Penelitian dan Pengembangan Industri,

Dep. Perindustrian, Jalan Gatot Subroto Kav.52-53,

Jakarta; E-mail : andriati@kemenperind.go.id

2 Peneliti Pertama UPT Hujan Buatan BPP Teknologi, Jalan MH. Thamrin no. 8, Gd.I Lt.19, Jakarta Pusat

E-mail : buhar04@yahoo.com
}

DAS Citarum merupakan tempat keberadaan 3 waduk besar (Saguling, Cirata dan Jatiluhur) yang menghasilkan daya listrik 5 milyar kwh/tahun atau setara dengan 16 juta ton BBM/tahun, mengairi jaringan irigasi pertanian seluas 300.000 ha di kawasan Pantura Jawa Barat, dan menjadi sumber air minum bagi kawasan urban Bandung, Cimahi, Cianjur, Purwakarta, Bekasi, Karawang dan Jakarta.

DAS Citarum telah menjadi sumber kehidupan dan penghidupan masyarakat Jawa Barat khususnya serta DKI Jakarta pada umumnya. Pada DAS ini bermukim 11,255 juta penduduk dengan sekitar lebih dari 1.000 industri yang sekaligus sebagai sumber pencemaran paling dominan (Wangsaatmaja, 2005).

Kondisi pencemaran air di suatu perairan dapat diindikasikan dengan mengetahui keberadaan atau besar kecilnya muatan oksigen di dalam air. Untuk menentukan status muatan oksigen di dalam air perlu dilakukan pengukuran besarnya BOD (Biological Oxygen Demand) atau kebutuhan oksigen biologis untuk memecah bahan buangan di dalam air oleh mikroorganisme, dan atau COD (Chemical Oxygen Demand) atau kebutuhan oksigen kimia untuk reaksi oksidasi terhadap bahan buangan di dalam air. BOD adalah angka indeks oksigen yang diperlukan oleh bahan pencemar yang dapat teruraikan (biodegradable 
pollutant) di dalam suatu sistem perairan selama berlangsungnya proses dekomposisi aerobic. BOD juga dapat diartikan sebagai angka indeks untuk tolok ukur tingkat pencemar dari limbah yang berada dalam suatu sistem perairan (Asdak, 1995).

Kebutuhan air bersih yang sangat mendesak, mengharuskan masalah pencemaran air di DAS Citarum perlu segera diatasi. Sebagai salah satu upaya mengatasi permasalahan tersebut, langkah pertama adalah mengetahui sebaran tingkat pencemaran yang ada. Sistem Informasi Geografis (SIG) sebagai suatu sistem yang mampu mengumpulkan, menyimpan, mentransformasikan, menampilkan dan mengkorelasi data spasial serta fenomena geografis, dapat digunakan untuk memperoleh sebaran tingkat pencemaran. SIG adalah suatu sistem informasi yang dirancang berdasarkan letak spasial atau koordinat geografis dari suatu obyek atau fenomena di permukaan bumi. Aronoff (1989) mendefinisikan SIG sebagai suatu sistem berbasis komputer yang memiliki kemampuan untuk menangani data spasial yaitu masukan (input), pengelolaan data (penyimpanan dan pengaktifan kembali), manipulasi dan analisis, serta keluaran (output).

Aplikasi SIG meliputi kegiatan inventarisasi, pemetaan, monitoring dan pemodelan (modelling). Saat ini SIG sudah banyak digunakan untuk berbagai keperluan, mulai dari inventarisasi sumberdaya alam, tata ruang wilayah, utilities (jaringan listrik, telpon), hingga untuk keperluan bisnis (misalnya untuk sistem stok dan distribusi). Salah satu produk SIG adalah dalam bentuk peta. Sebuah peta pada dasarnya merupakan sekumpulan informasi yang diperoleh dari proses pengolahan dan analisis data. Informasi yang terkandung dalam sebuah peta dapat digunakan untuk pengambilan keputusan atau penentuan kebijaksanaan (decision support). Penggunaan teknik penginderaan jauh yang dipadukan dengan SIG diharapkan dapat menyediakan data dan menganalisis data secara spasial, sehingga dapat menghasilkan informasi yang dapat dipakai untuk mengambil keputusan yang bersifat integratif.

Tujuan dari penelitian ini adalah untuk mendapatkan gambaran secara spasial kondisi tingkat pencemaran air DAS Citarum dalam bentuk Peta Tingkat Pencemaran Air DAS Citarum berdasarkan data pengukuran sampel kualitas air. Hasil penelitian diharapkan dapat menjadi rekomendasi pengambilan keputusan dalam pengelolaan DAS Citarum.

\section{METODE PENELITIAN}

Data yang digunakan dalam penelitian ini seluruhnya diperoleh dari Perusahaan Umum Jasa Tirta II (PJT II), selaku otorita pengelola Waduk Jatiluhur yang wilayah operasionalnya berada di dalam DAS Citarum. Data tersebut adalah data kualitas air dan data spasial yang berupa peta dasar dan peta-peta tematik serta citra satelit Landsat Thematic Mapper daerah penelitian.

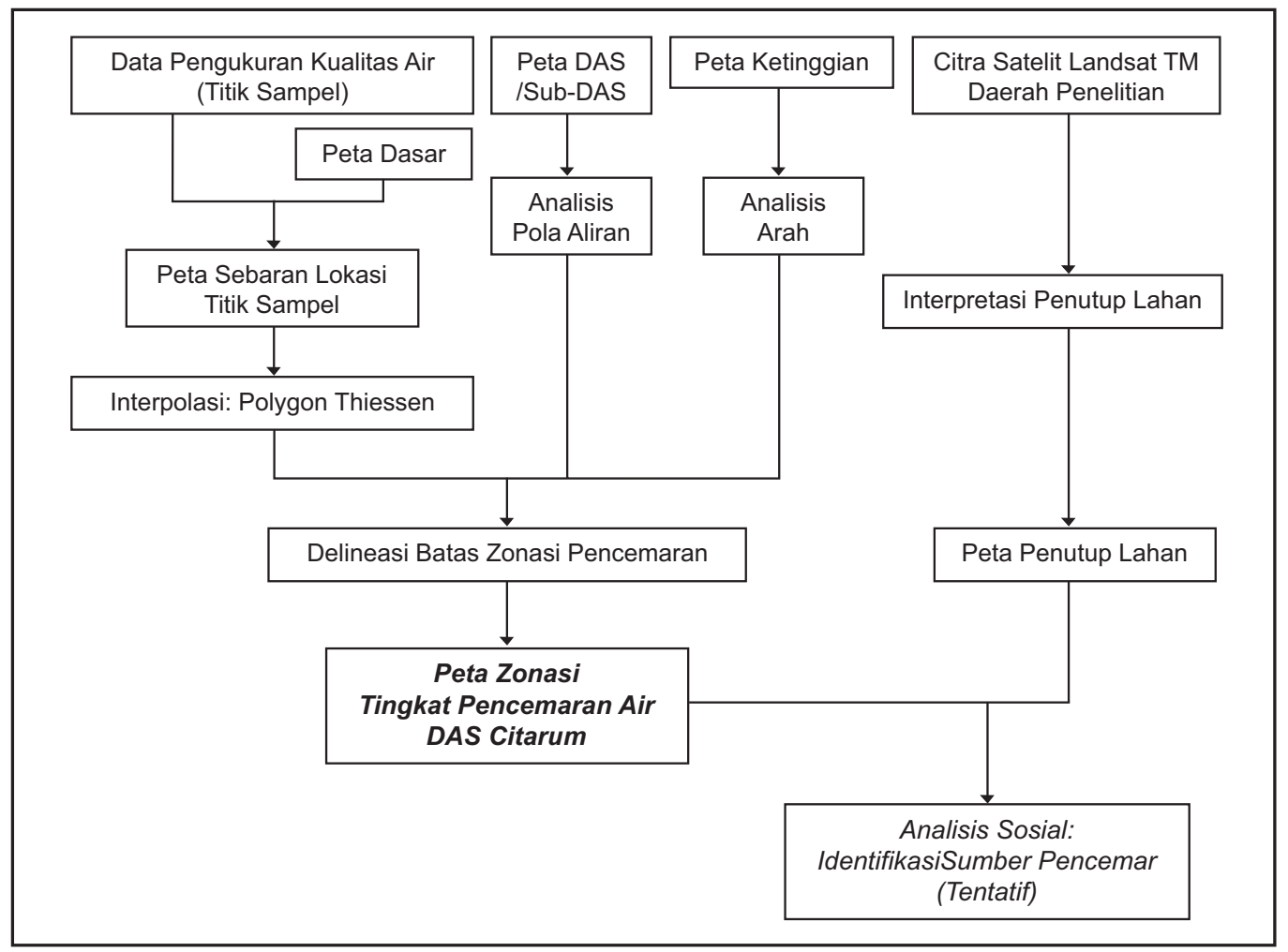

Gambar 1. Diagram Alir Penelitian 
Diagram alir penelitian disajikan pada Gambar 1.

Data kualitas air merupakan sekumpulan data hasil pengukuran besarnya nilai kandungan Biochemical Oxygen Demand (BOD) dari 33 lokasi titik sampel (C1-C14 dan C27-C45) yang tersebar di dalam DAS Citarum selama 6 tahun, yaitu sejak tahun 1994 sampai dengan tahun 1999. Nilai kandungan BOD dari seluruh titik sampel selanjutnya diplotkan ke dalam peta dasar. Hasil plot dalam bentuk titik kemudian diinterpolasi menggunakan metode Poligon Thiessen untuk memperoleh gambaran spasial dalam bentuk suatu area (zonasi). Batas zonasi dari metode ini masih bersifat tentatif (karena bentuknya kaku). Oleh karena itu selanjutnya ditumpangsusunkan (overlay) dengan informasi pola aliran dan arah aliran untuk mendapatkan batas zonasi yang lebih akurat dan lebih halus (smooth).

Peta dasar dan peta-peta tematik merupakan data spasial (bereferensi geografis) yang dibuat berdasarkan data vektor dalam format digital (hasil proses digitasi), berisikan layer batas administrasi, sungai, kontur, batas DAS dan sub-DAS, lereng dan ketinggian. Data vektor digital yang tersedia disusun menjadi peta dasar dan peta tematik berupa Peta Batas sub-DAS untuk mendapatkan informasi pola aliran dan Peta Ketinggian untuk memperoleh informasi arah aliran sungai. Kedua informasi ini selanjutnya dijadikan parameter masukan guna memperhalus (smoothing) batas zonasi dari hasil proses interpolasi menggunakan metode Poligon Thiessen. Dalam penelitian ini digunakan citra satelit Landsat Thematic Mapper daerah penelitian hasil perekaman tahun 2000, yang telah diproses dalam bentuk komposit menggunakan saluran (band) 452 (Gambar 2).

Peta tematik penutup lahan diperoleh dari hasil proses interpretasi citra satelit. Interpretasi dilakukan dengan membuat klasifikasi multispektral menggunakan software ER Mapper ver. 6.3 yang mempunyai kemampuan melakukan image processing. Hasil proses interpretasi citra satelit Landsat yang berupa Peta Tematik Penutup Lahan selanjutnya ditumpangsusunkan (overlay) dengan Peta Zonasi Tingkat Pencemaran Air sebagai bahan masukan dalam analisis spasial untuk mengidentifikasi sumber-sumber pencemar air yang bersifat tentatif.

\section{HASIL DAN PEMBAHASAN}

Hasil pengumpulan data berupa nilai BOD dari 33 titik sampel tahun 1994-1999 disajikan pada Tabel 1. Nilai rata-rata dari setiap titik selama 6 tahun bervariasi tergantung lokasi pengambilan sampel. Nilai BOD tertinggi yaitu C39 $(378,87 \mathrm{mg} / \mathrm{l})$ berlokasi di Cimahi Selatan, Kabupaten Bandung. Nilai BOD terendah yaitu C38 (4,12 mg/l) berlokasi di Cisarua, Kabupaten Bandung.

\subsection{Kondisi Tingkat Pencemaran Air di DAS Citarum}

Tingkat pencemaran air di DAS Citarum terbagi atas 4 zonasi, yaitu zona agak tercemar $(<0,1 \mathrm{mg} / \mathrm{l})$, kritis tercemar $(0,1-1 \mathrm{mg} / \mathrm{l})$, sangat

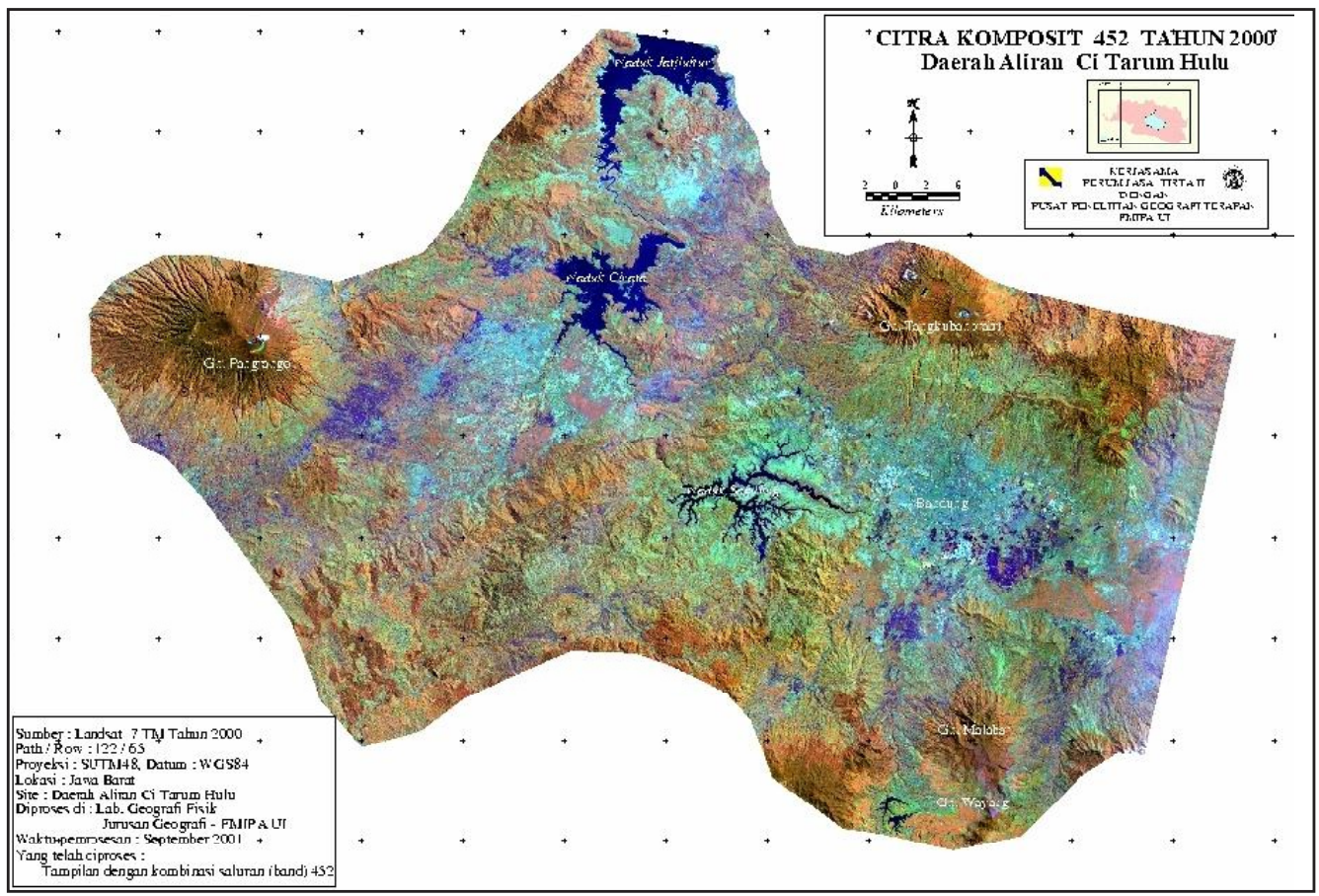

Gambar 2. Citra Landsat TM Komposit 452 Daerah Penelitian (Tahun 2000) 
Tabel 1. Kandungan BOD Pada Lokasi Titik Sampel di DAS Citarum (mg/1)

\begin{tabular}{|c|c|c|c|c|c|c|c|c|c|}
\hline \multirow{2}{*}{$\begin{array}{l}\text { LOKASI } \\
\text { SAMPEL }\end{array}$} & \multirow{2}{*}{ KECAMATAN } & \multirow{2}{*}{ KABUPATEN } & \multicolumn{6}{|c|}{ TAHUN } & \multirow{2}{*}{$\begin{array}{l}\text { RATA- } \\
\text { RATA }\end{array}$} \\
\hline & & & 1994 & 1995 & 1996 & 1997 & 1998 & 1999 & \\
\hline $\mathrm{C} 1$ & PACET & KAB. BANDUNG & 3.20 & 2.66 & 14.18 & 2.05 & 1.80 & 2.61 & 4.42 \\
\hline $\mathrm{C} 2$ & IBUN & KAB. BANDUNG & 5.98 & 5.40 & 25.12 & 4.03 & 4.48 & 7.39 & 8.74 \\
\hline $\mathrm{C} 3$ & MAJALAYA & KAB. BANDUNG & 20.51 & 23.89 & 37.85 & 17.35 & 18.91 & 20.88 & 23.23 \\
\hline $\mathrm{C} 4$ & MAJALAYA & KAB. BANDUNG & 24.48 & 22.87 & 47.42 & 25.10 & 40.94 & 28.67 & 31.58 \\
\hline $\mathrm{C} 5$ & BOJONGSOANG & KAB. BANDUNG & 26.86 & 26.11 & 61.15 & 30.17 & 50.38 & 33.50 & 38.03 \\
\hline $\mathrm{C} 6$ & BALEENDAH & KAB. BANDUNG & 35.27 & 39.47 & 25.90 & 41.73 & 90.03 & 55.84 & 48.04 \\
\hline $\mathrm{C} 7$ & DAYEUHKOLOT & KAB. BANDUNG & 38.66 & 37.57 & 54.52 & 33.57 & 56.68 & 31.73 & 42.12 \\
\hline $\mathrm{C} 8$ & SOREANG & KAB. BANDUNG & 40.48 & 33.79 & 68.41 & 31.65 & 40.93 & 22.34 & 39.60 \\
\hline C9 & BATUJAJAR & KAB. BANDUNG & 68.80 & 57.43 & 54.51 & 65.55 & 100.28 & 38.58 & 64.19 \\
\hline $\mathrm{C} 10$ & CIPONGKOR & KAB. BANDUNG & 13.58 & 13.85 & 31.31 & 25.93 & 29.23 & 11.78 & 20.94 \\
\hline $\mathrm{C} 11$ & CIPONGKOR & KAB. BANDUNG & 10.53 & 10.53 & 24.61 & 18.47 & 17.15 & 7.62 & 14.82 \\
\hline $\mathrm{C} 12$ & MANIIS & KAB. PURWAKARTA & 6.08 & 6.54 & 21.23 & 8.65 & 10.02 & 8.42 & 10.16 \\
\hline $\mathrm{C} 13$ & MANIIS & KAB. PURWAKARTA & 6.10 & 6.59 & 19.61 & 4.11 & 9.16 & 6.03 & 8.60 \\
\hline $\mathrm{C} 14$ & JATILUHUR & KAB. PURWAKARTA & 2.58 & 3.21 & 14.83 & 3.00 & 4.08 & 7.03 & 5.79 \\
\hline $\mathrm{C} 27$ & CIPARAY & KAB. BANDUNG & 9.11 & 7.87 & 24.32 & 10.38 & 10.83 & 8.10 & 11.77 \\
\hline $\mathrm{C} 28$ & BOJONGSOANG & KAB. BANDUNG & 14.82 & 15.71 & 26.58 & 14.95 & 31.23 & 25.23 & 21.42 \\
\hline $\mathrm{C} 29$ & CIMENYAN & KAB. BANDUNG & 5.18 & 5.61 & 5.03 & 6.40 & 5.70 & 7.40 & 5.89 \\
\hline $\mathrm{C} 30$ & BOJONGSOANG & KAB. BANDUNG & 89.46 & 87.03 & 84.97 & 116.20 & 180.72 & 150.07 & 118.07 \\
\hline $\mathrm{C} 31$ & LEMBANG & KAB. BANDUNG & 7.85 & 10.53 & 43.31 & 7.03 & 2.09 & 2.60 & 12.23 \\
\hline $\mathrm{C} 32$ & DAYEUHKOLOT & KAB. BANDUNG & 34.31 & 38.70 & 23.14 & 29.55 & 28.81 & 30.27 & 30.80 \\
\hline $\mathrm{C} 33$ & BANJARAN & KAB. BANDUNG & 5.61 & 5.13 & 6.12 & 7.60 & 6.76 & 8.00 & 6.54 \\
\hline $\mathrm{C} 34$ & BALEENDAH & KAB. BANDUNG & 34.86 & 49.33 & 20.23 & 17.05 & 31.33 & 27.83 & 30.11 \\
\hline $\mathrm{C} 35$ & SOREANG & KAB. BANDUNG & 7.45 & 7.24 & 8.78 & 7.24 & 5.43 & 5.17 & 6.88 \\
\hline $\mathrm{C} 36$ & LEMBANG & KAB. BANDUNG & 7.12 & 7.45 & 4.64 & 5.30 & 5.14 & 5.07 & 5.79 \\
\hline $\mathrm{C} 37$ & MARGAASIH & KAB. BANDUNG & 91.01 & 95.10 & 60.48 & 64.85 & 65.14 & 66.90 & 73.91 \\
\hline $\mathrm{C} 38$ & CISARUA & KAB. BANDUNG & 5.07 & 5.20 & 4.98 & 3.55 & 3.04 & 2.90 & 4.12 \\
\hline $\mathrm{C} 39$ & CIMAHI SELATAN & KAB. BANDUNG & 424.23 & 259.21 & 400.03 & 390.30 & 451.70 & 347.77 & 378.87 \\
\hline $\mathrm{C} 40$ & CIPEUNDEUY & KAB. BANDUNG & 11.42 & 6.90 & 11.86 & 11.00 & 8.33 & 6.80 & 9.39 \\
\hline $\mathrm{C} 41$ & SUKALUYU & KAB. CIANJUR & 8.91 & 8.16 & 8.23 & 8.83 & 8.97 & 8.37 & 8.58 \\
\hline $\mathrm{C} 42$ & SUKALUYU & KAB. CIANJUR & 6.95 & 6.33 & 8.58 & 9.30 & 9.73 & 9.07 & 8.33 \\
\hline $\mathrm{C} 43$ & MANDE & KAB. CIANJUR & 5.20 & 5.16 & 5.27 & 6.78 & 5.74 & 5.23 & 5.56 \\
\hline $\mathrm{C} 44$ & CIKALONG KULON & KAB. CIANJUR & 5.74 & 5.19 & 5.32 & 6.45 & 5.28 & 5.20 & 5.53 \\
\hline $\mathrm{C} 45$ & MANIIS & KAB. PURWAKARTA & 7.23 & 5.98 & 7.74 & 6.75 & 6.18 & 4.67 & 6.43 \\
\hline
\end{tabular}

Sumber : Perum Jasa Tirta II

tercemar (1-2 mg/l), dan tercemar berat (>2 mg/l). Gambar 3 merupakan peta yang menunjukkan batas zonasi tiap wilayah pencemaran. Secara keseluruhan, lebih dari separuh luas DAS Citarum kondisi tingkat pencemaran airnya masih dalam kategori agak tercemar $(54,46 \%)$, sisanya adalah $11,99 \%$ termasuk dalam kelas kritis tercemar, $16,07 \%$ masuk dalam kelas sangat tercemar dan $17,49 \%$ dalam kondisi tercemar berat.

\subsubsection{Zona Agak Tercemar}

Zona agak tercemar terdapat di dua area, yaitu di sisi barat-utara dan sisi selatan DAS Citarum. Zona ini paling dominan dibandingkan zona lainnya. Total luas zona ini adalah $248.404,76$ ha atau $54,46 \%$ dari luas keseluruhan DAS Citarum. Area pertama dari zonasi ini seluas 180.060,11 ha, meliputi sub-DAS Cisokan dan Cikundul di wilayah Kabupaten Cianjur pada sisi bagian barat DAS Citarum, serta sub-DAS Citarum (Jatiluhur) - Ci
Kao di wilayah Kabupaten Purwakarta, sebagian sub-DAS Cimeta, juga sebagian kecil sub-DAS Ci Kapundung dan Citarik yang termasuk dalam wilayah Kabupaten Bandung dan Sumedang pada bagian utara DAS Citarum. Area kedua berada pada sisi selatan DAS Citarum seluas 68.344,66 ha, yang meliputi sub-DAS Ciwidey, Ci Sangkeuy dan Citarum Hulu yang masuk ke dalam wilayah Kabupaten Bandung (Gambar 3).

\subsubsection{Zona Kritis Tercemar}

Zona kritis tercemar terdapat di tiga lokasi dalam DAS Citarum dengan total area yang tidak terlalu luas yaitu $54.686,95$ ha atau $11,99 \%$ dari luas keseluruhan DAS Citarum. Area pertama terletak di bagian tengah DAS Citarum, dengan luas $39.748,29$ ha, meliputi sub-DAS Cisokan di Kabupaten Cianjur dan sebagian kecil subDAS Cimeta di Kabupaten Bandung. Area kedua berada di sebelah timur laut DAS Citarum, dengan 


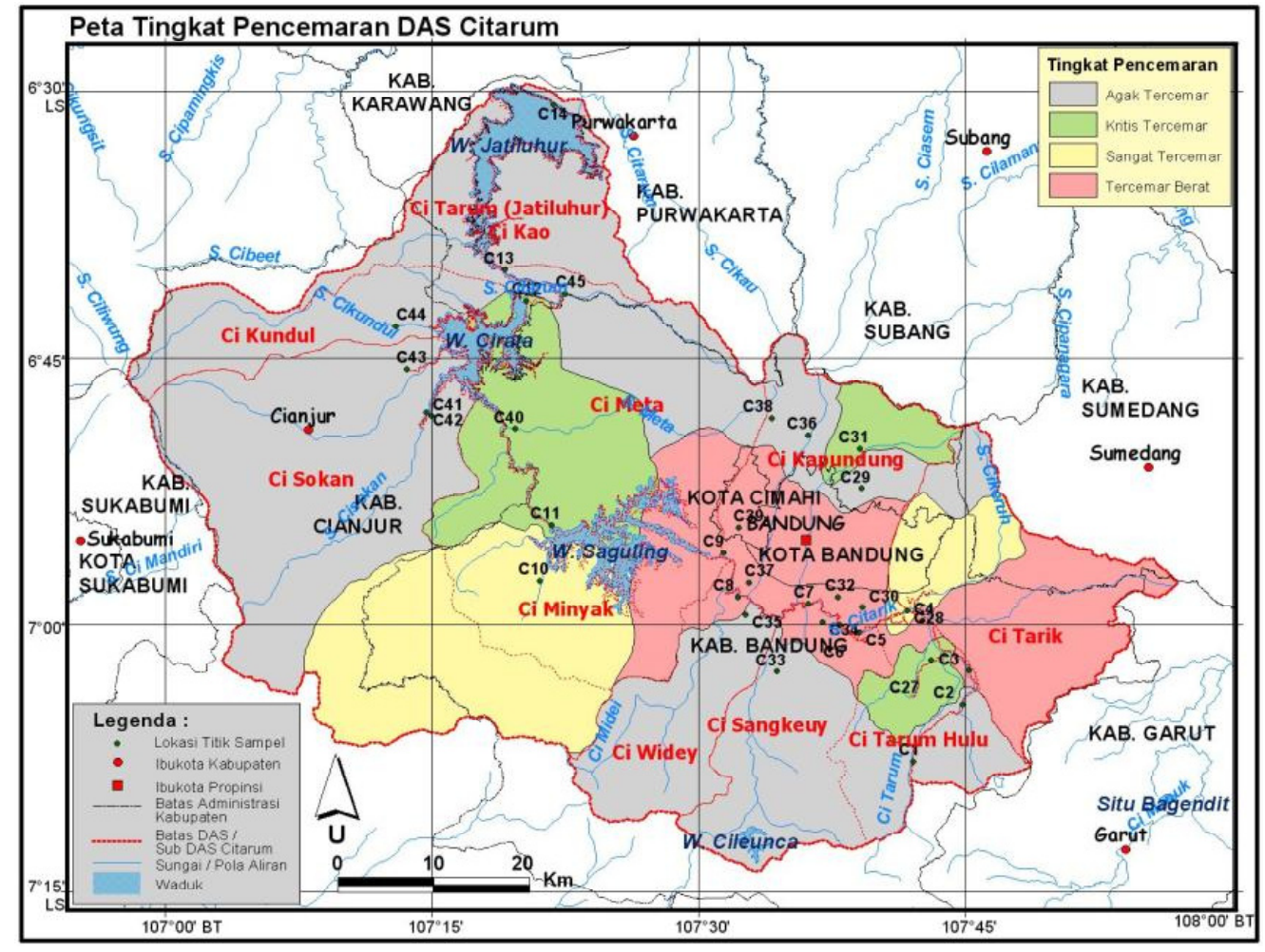

Gambar 3. Peta Zonasi Tingkat Pencemaran Air DAS Citarum

\subsubsection{Zona Sangat Tercemar}

Zona sangat tercemar terdapat pada dua lokasi, yaitu di sebelah selatan dan timur dari DAS Citarum dengan luas $73.282,05$ ha atau $16,07 \%$ dari luas keseluruhan DAS Citarum. Area pertama yang terletak di sebelah timur memiliki luas sebesar $60.962,29$ ha. Area ini meliputi dua sub-DAS, yaitu Cisokan dan Ciminyak yang secara administratif berada di Kabupaten Cianjur dan Kabupaten Bandung. Area kedua berada di sebelah selatan dengan luas 12.319,76 ha, meliputi sub-DAS Citarik serta sebagian kecil sub-DAS Ci Kapundung dan Citarum Hulu. Secara administratif, area kedua ini masuk ke dalam wilayah Kota Bandung, Kabupaten Bandung dan Kabupaten Sumedang (Gambar 3).

\subsubsection{Zona Tercemar Berat}

Zona tercemar berat hanya terdapat dalam satu area, memanjang mulai dari bagian tengah hingga ke sisi paling timur dari DAS Citarum. Luasnya $79.779,88$ ha atau $17,49 \%$ dari luas keseluruhan DAS Citarum. Yang termasuk dalam zona ini adalah sub-DAS Cimeta bagian tenggara, Ci Kapundung bagian selatan, Ciminyak bagian timur, Ciwideuy, Cisangkeuy dan Citarum Hulu bagian utara, serta Citarik bagian selatan. Secara administratif, zona ini meliputi wilayah Kota Cimahi, Kota Bandung, Kabupaten Bandung dan sebagian kecil wilayah Kabupaten Sumedang (Gambar 3).

Gambar 4 menunjukkan tingkat pencemaran air masing-masing sub-DAS. Dari keseluruhan subDAS yang ada di DAS Citarum, sub-DAS Ci Kundul dan Citarum (Jatiluhur) - Ci Kao yang berada di sebelah utara serta sub-DAS Ci Sokan di sebelah barat, merupakan daerah yang relatif paling rendah tingkat pencemaran airnya. Tingkat pencemaran air paling tinggi terjadi di sub-DAS Ci Kapundung yang berada di wilayah Kota Bandung dan Cimahi serta sub-DAS Ci Tarik yang berada di sisi paling timur dari DAS Citarum. 


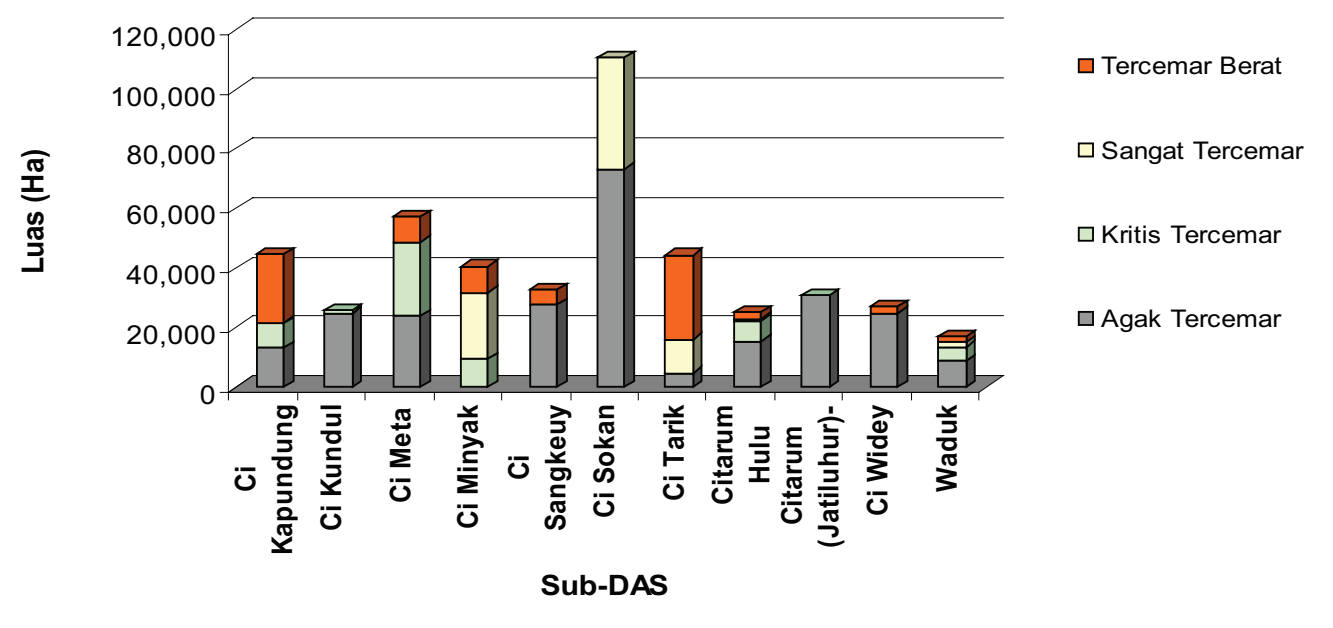

Gambar 4. Tingkat Pencemaran Air Pada Masing-masing sub-DAS

\subsection{Kondisi Penutup Lahan DAS Citarum}

Berdasarkan Peta Penutup Lahan hasil interpretasi citra satelit Landsat TM wilayah DAS Citarum perekaman tahun 2000, jenis penutup lahan yang paling dominan adalah sawah, hutan dan kebun campuran yang mempunyai luasan di atas $20 \%$. Permukiman hanya $5,23 \%$ dan industri $0,49 \%$. Luasan masing-masing jenis penutup lahan di DAS Citarum disajikan dalam Tabel 2 dan distibusi spasialnya disajikan dalam Gambar 5.

Gambar 5 menunjukkan bahwa pada daerah yang kondisi tingkat pencemarannya paling ringan yaitu sub-DAS Ci Sokan, Ci Kundul dan Citarum (Jatiluhur) - Ci Kao, tutupan vegetasi sangat dominan di wilayah ini. Jenis penutup lahannya mayoritas berupa hutan, sawah, kebun campuran dan perkebunan. Sebaliknya pada sub DAS yang paling tercemar, yaitu sub-DAS Ci Kapundung dan Ci Tarik yang terletak di wilayah Kota Bandung, Kota Cimahi dan Kabupaten Bandung sebelah timur, luasan permukiman lebih dominan dibandingkan hutan. Luas permukiman dan juga industri pada wilayah zonasi tercemar berat, meningkat pesat (hampir sekitar 4 kali lipat) dibandingkan dengan penutup lahan sejenis pada ketiga zonasi pencemaran yang lain. Luas sawah pada zonasi tercemar berat paling tinggi dibandingkan luas sawah pada zonasi lain. Sebaliknya untuk hutan, pada zonasi tercemar berat luasannya jauh lebih berkurang dibandingkan pada ketiga zonasi pencemaran yang lain. Hal ini dapat terlihat lebih jelas pada Gambar 6

Tabel 2. Penutup Lahan di DAS Citarum

\begin{tabular}{|c|c|c|}
\hline Jenis Penutup Lahan & Luas (Ha) & Luasan ( \% ) \\
\hline Hutan & $114,724.88$ & 25.15 \\
\hline Industri & $2,224.32$ & 0.49 \\
\hline Kebun Campuran & $101,385.79$ & 22.23 \\
\hline Lapangan Terbang & 202.28 & 0.04 \\
\hline Padang Rumput & $1,239.08$ & 0.27 \\
\hline Pemukiman & $23,841.06$ & 5.23 \\
\hline Perkebunan & $32,086.67$ & 7.03 \\
\hline Sawah & $118,814.82$ & 26.05 \\
\hline Semak Belukar & 591.39 & 0.13 \\
\hline Tanah Rusak & 249.89 & 0.05 \\
\hline Tegalan & $44,546.11$ & 9.77 \\
\hline Waduk & $16,247.36$ & 3.56 \\
\hline Total & $456,153.65$ & 100.00 \\
\hline
\end{tabular}

Sumber : Hasil interpretasi Citra Landsat (2000) 


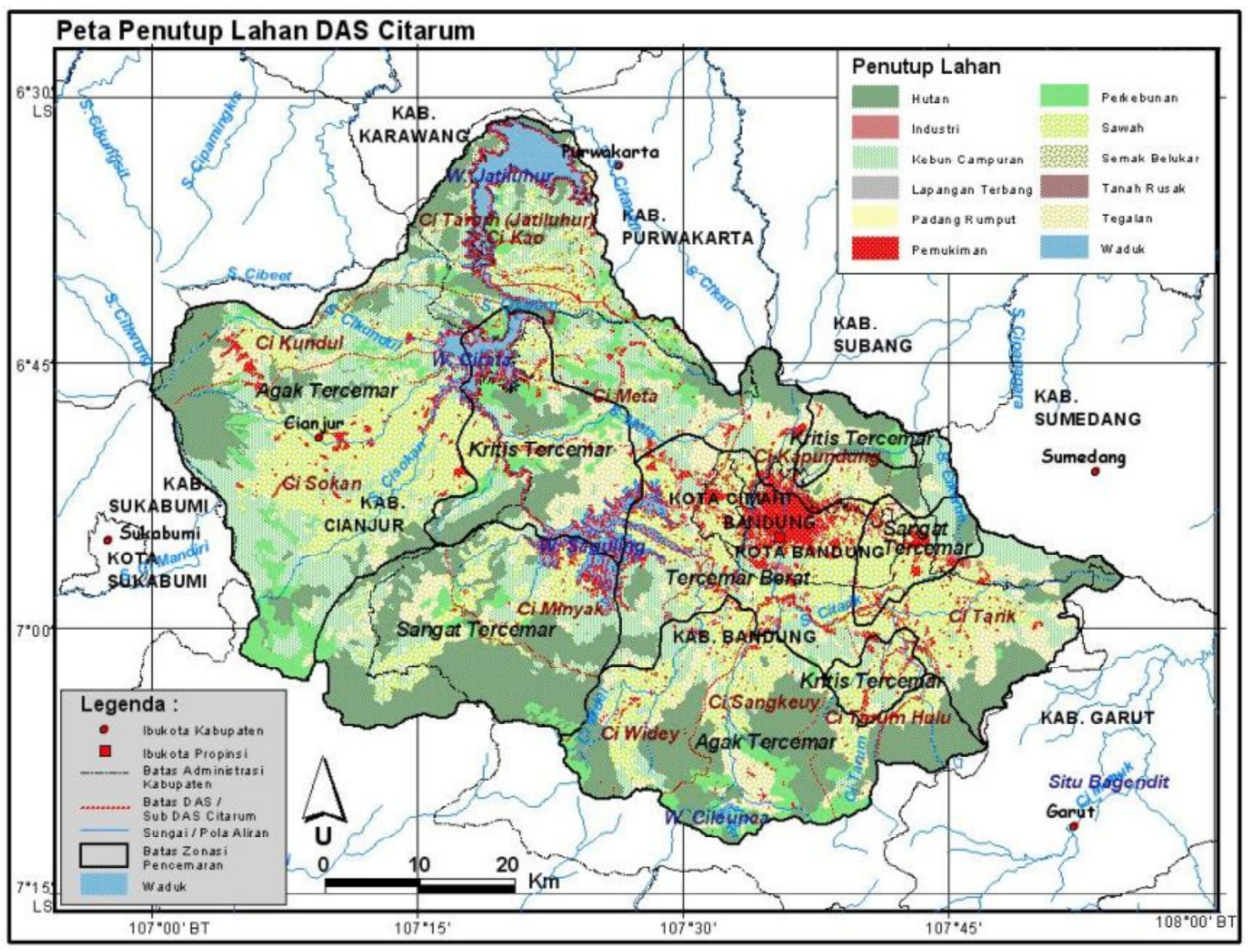

Gambar 5. Kondisi Penutup Lahan DAS Citarum (tahun 2000)

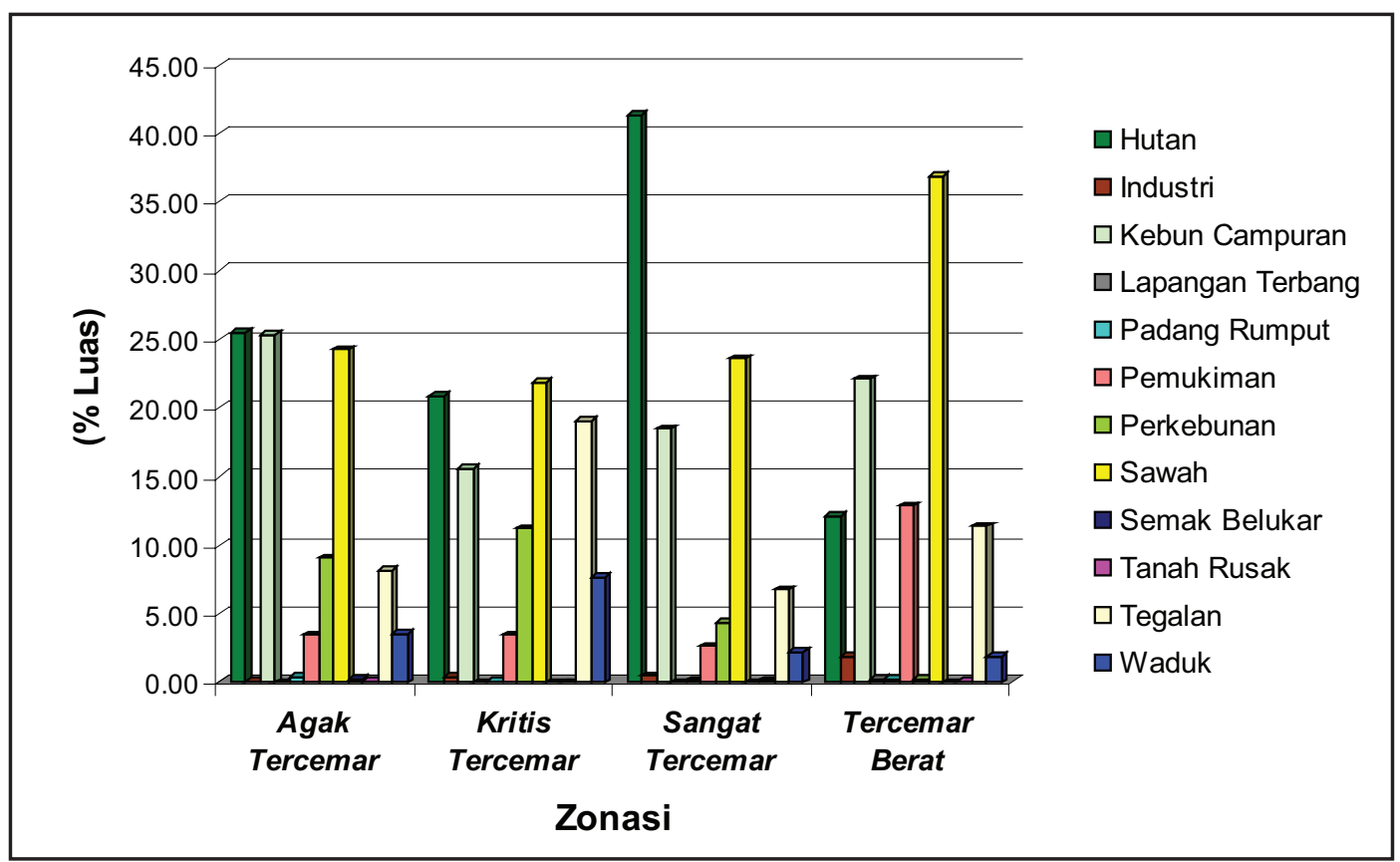

Gambar 6. Hubungan Tingkat Pencemaran Air dengan Luas Jenis Penutup Lahan

\subsection{Identifikasi Sumber Pencemar}

Sumber pencemaran air yang dapat diidentifikasi dari penelitian ini hanya bersifat nonpoint sources (berasal dari daerah yang tidak dapat dikenali secara pasti) berdasarkan analisis spasial hasil proses overlay antara Peta Zonasi Pencemaran Air dengan Peta Penutup Lahan. Hasil penelitian menunjukkan bahwa sumber-sumber pencemaran adalah lokasi-lokasi permukiman, sawah dan industri 
Pada beberapa penelitian yang pernah dilakukan di DAS Citarum, diketahui bahwa persentase beban pencemaran BOD di sungai Citarum Hulu berdasarkan lokasi dari hulu ke hilir pada tahun 2001 didominasi oleh domestik (44,33-54\%), industri (0-42,33\%), pertanian $(10,35-35,39 \%)$, dan peternakan $(2,99-10,26 \%)$. Hasil penelitian tersebut menunjukkan bahwa limbah yang dihasilkan oleh rumah tangga lebih banyak dibandingkan industri. Meski demikian, perlu dilakukan penelitian lebih lanjut mengenai jenis industri yang ada dan limbah yang dihasilkan (kualitas dan kuantitas), terutama di wilayah yang tercemar berat dan sangat tercemar.

Berdasarkan peta tingkat pencemaran di DAS Citarum yang dihasilkan dari penelitian ini, dapat diketahui wilayah yang akan menjadi prioritas dalam penanganan pencemaran, sehingga dapat dilakukan penelitian lebih lanjut pada wilayah prioritas tersebut. Secara khusus, hasil penelitian diharapkan dapat digunakan sebagai bahan untuk memperoleh informasi lebih lanjut mengenai lokasilokasi yang memberikan kontribusi sebagai sumber pencemaran air di DAS Citarum.

Area permukiman pada area zona tercemar berat, yaitu di Kota Bandung dan Kota Cimahi (seperti yang telah diperlihatkan dalam Gambar 5) yang lebih padat dibandingkan area lainnya membuktikan bahwa daerah permukiman merupakan salah satu yang menjadi sumber pencemaran air di DAS Citarum. Jenis limbah yang berasal dari daerah pemukiman (limbah domestic) biasanya berupa sampah organik dan sampah anorganik serta deterjen. Sampah organik adalah sampah yang dapat diuraikan atau dibusukkan oleh bakteri. Contohnya sisa-sisa sayuran, buahbuahan, dan daun-daunan. Sedangkan sampah anorganik seperti kertas, plastik, gelas atau kaca, kain, kayu-kayuan, logam, karet, dan kulit. Sampahsampah ini tidak dapat diuraikan oleh bakteri (non biodegrable). Dalam kaitannya dengan konsentrasi BOD yang dijadikan sebagai parameter tingkat pencemaran, sampah organik yang dibuang ke sungai menyebabkan berkurangnya jumlah oksigen terlarut, karena sebagian besar digunakan bakteri untuk proses pembusukannya.

Deterjen merupakan limbah pemukiman yang paling potensial mencemari air. Pada saat ini hampir setiap rumah tangga menggunakan deterjen, padahal limbah deterjen sangat sukar diuraikan oleh bakteri sehingga tetap aktif untuk jangka waktu yang lama. Penggunaan deterjen secara besar-besaran juga meningkatkan senyawa fosfat pada air sungai yang dapat merangsang pertumbuhan ganggang dan eceng gondok.

Dari area pertanian (sawah), penggunaan pupuk dan pestisida yang berlebihan dapat mencemari air. Limbah pupuk juga mengandung fosfat yang dapat merangsang pertumbuhan gulma air seperti ganggang dan eceng gondok, sama halnya dengan deterjen dari limbah permukiman. Limbah pestisida mempunyai aktifitas dalam jangka waktu yang lama dan ketika terbawa aliran air keluar dari daerah pertanian, dapat mematikan hewan yang bukan sasaran seperti ikan, udang dan hewan air lainnya. Pestisida mempunyai sifat relatif tidak larut dalam air, tetapi mudah larut dan cenderung konsentrasinya meningkat dalam lemak dan sel-sel tubuh mahluk hidup disebut Biological Amplification, sehingga apabila masuk dalam rantai makanan konsentrasinya akan semakin tinggi dan yang tertinggi adalah pada konsumen puncak.

Hasil kajian Balai Lingkungan Keairan Pusat Penelitian dan Pengembangan Sumberdaya Air tentang Studi Pengendalian Pencemaran Air Berbasis Kluster Industri di DAS Citarum (1998) menyebutkan bahwa di sekitar Kota Bandung dan Kota Cimahi terdapat banyak sekali industri, seperti yang ditunjukkan pada Gambar 7. Hal ini juga mengindikasikan bahwa banyaknya industri di daerah tersebut turut berperanan menjadi sumber pencemaran air sehingga menyebabkan kawasan Bandung dan sekitarnya merupakan zone yang paling berat tingkat pencemarannya.

Pada umumnya limbah industri mengandung limbah B3, yaitu bahan berbahaya dan beracun. Menurut PP 18 tahun 99 pasal 1, limbah B3 adalah sisa suatu usaha atau kegiatan yang mengandung bahan berbahaya dan beracun yang dapat mencemarkan atau merusak lingkungan hidup sehingga membahayakan kesehatan serta kelangsungan hidup manusia dan mahluk lainnya. Karakteristik limbah B3 adalah korosif/ menyebabkan karat, mudah terbakar dan meledak, bersifat toksik/ beracun dan menyebabkan infeksi/ penyakit. Limbah industri yang berbahaya antara lain yang mengandung logam dan cairan asam. Jenis limbah umumnya bersifat korosif, dapat mematikan tumbuhan dan hewan air. Pada manusia menyebabkan iritasi pada kulit dan mata, mengganggu pernafasan dan menyebabkan kanker. 


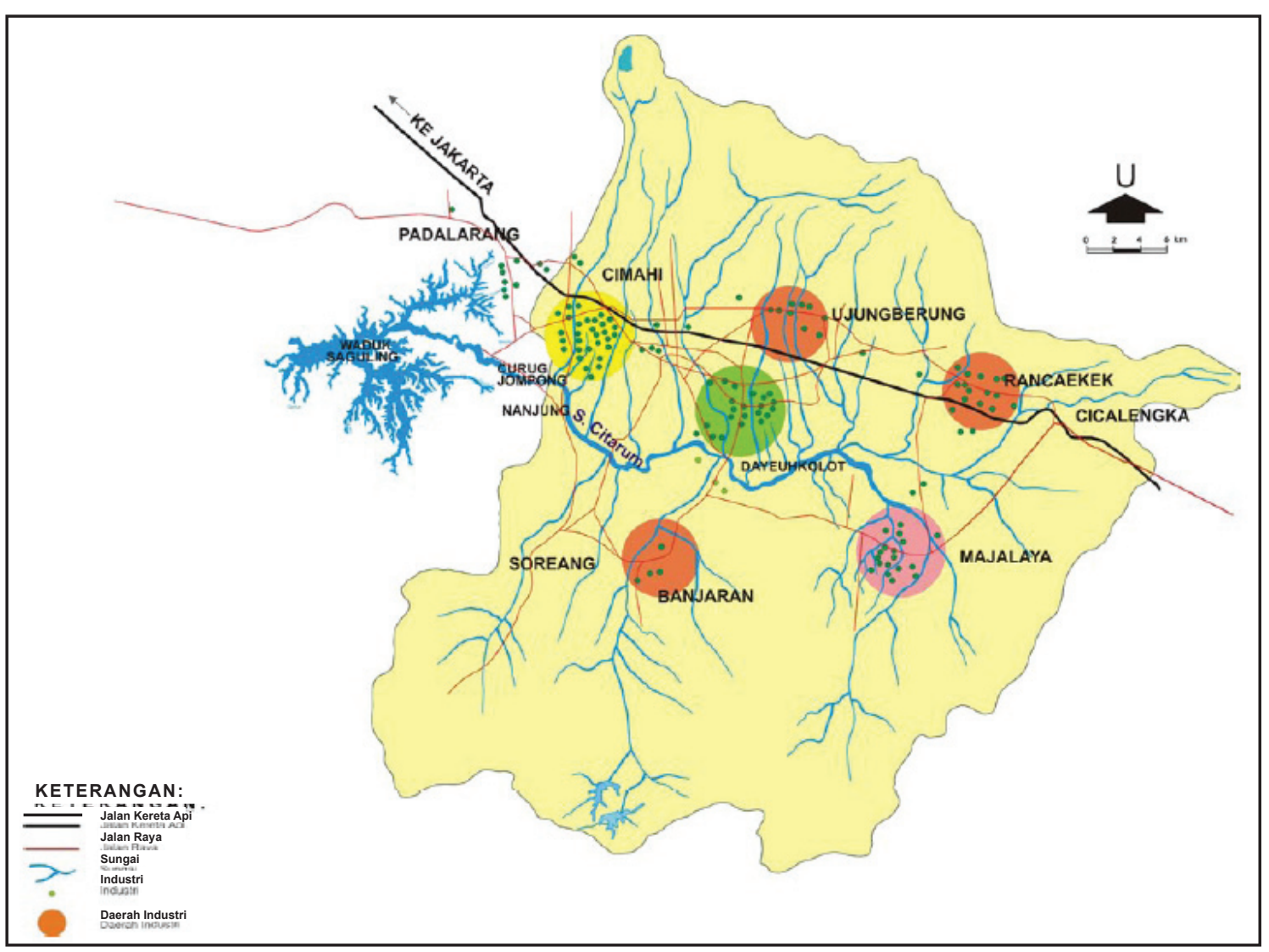

Gambar 7. Peta Sebaran Kluster Industri di DAS Citarum Hulu

\section{KESIMPULAN}

Hasil pemetaan menunjukkan bahwa SubDAS Ci Kundul dan Citarum (Jatiluhur) - Ci Kao yang berada di sebelah utara serta sub-DAS Ci Sokan di sebelah barat merupakan daerah yang relatif paling rendah tingkat pencemaran airnya. Tingkat pencemaran air paling tinggi terjadi di sub-DAS Ci Kapundung yang berada di wilayah Kota Bandung dan Cimahi serta sub-DAS Ci Tarik yang berada di sisi paling timur dari DAS Citarum. Luas permukiman, industri dan sawah pada zonasi tercemar berat jauh lebih tinggi dibandingkan dengan penutup lahan sejenis pada ketiga zonasi pencemaran yang lain. Sebaliknya untuk luas hutan pada zonasi tercemar berat jauh berkurang dibandingkan pada ketiga zonasi pencemaran yang lain. Hal tersebut sebagai indikasi bahwa sumber pencemaran adalah lokasi industri, permukiman dan sawah.

\section{DAFTAR PUSTAKA}

Aronoff, S. 1989. GIS : A Management Perspective. WDL Publications. Ottawa.
Asdak, C. 1995. Hidrologi dan Pengelolaan Daerah Aliran Sungai. Gadjah Mada University Press. Yogyakarta.

Douglas, W.J. 1995. Environmental GIS, Applications to Industrial Facilities. Lewis Publishers.

Lillesand and Kiefer. 1990. Penginderaan Jauh dan Interpretasi Citra. Gadjah Mada University Press. Yogyakarta.

Polii, B. 1994. Thesis. Kajian Konsep Pengukuran BOD Sebagai Indikator Pencemaran Bahan Organik di Perairan Daerah Tropis. Program Pasca Sarjana. Institut Pertanian Bogor. Bogor.

Wangsaatmaja, S. 2005. Tidak Ada Kata Esok Untuk Perbaikan Citarum. Pikiran Rakyat edisi 6 Juni 2005. Bandung.

Balai Lingkungan Keairan Pusat Penelitian dan Pengembangan Sumberdaya Air. 1998. Studi Pengendalian Pencemaran Air Berbasis Kluster Industri di DAS Citarum. Laporan Teknis. Puslitbang SDA Departemen Pekerjaan Umum. Bandung. 
